\title{
CHRONOLOGY OF EVENTS IN \\ DIVISION OF BIOLOGY AND MEDICINE PROGRAMS
}

Discovery of the specific mutagenic effects of ionizing radiation by Muller.

1936

December

1944

1946

August

1947
First cyclotron-produced radioisotope, phosphorus 32 , administered to a patient suffering from leukemia at University of California, Berkeley.

Initiation of first large scale mammalian genetics study (in mice) at the University of Rochester.

First shipment of reactor-produced radioisotope, carbon 14, to independent research group at the University of Pennsylvania.

Appointment of Medical Board of Review which recommended establishment of a Division of Biology and Medicine. Appointment of a permanent Advisory Committee for Biology and Medicine.

Arrangement with the National Research Council for longrange studies of the effects of atomic bombings on Japanese survivors in Hiroshima and Nagasaki.

Establishment of Medical Division, New York Operations office (Changed in 1949 to the Health and Safety Division; in 1953 became the Health and Safety Laboratory.)

July 30

Formulation of a cancer research program including provision of beds for selected cancer patients in hospitals at the Clinton, Brookhaven, and Los Alamos Laboratories and elsewhere.

The Commission took over from the Office of Naval Research financial support of 28 projects in the biomedical fields of research pertinent to the mission of the AEC.

Bikini and New Mexico surveys undertaken to study effects of atomic explosions on marine, plant, and animal life.

Proposal for use of cobalt 60 in teletherapy unit at the Oak Ridge Institute of Nuclear Studies. 


\section{DISCLAIMER}

Portions of this document may be illegible in electronic image products. Images are produced from the best available original document. 
1949

The Commission approved plans for the 50-bed Argonne Cancer Research Hospital and for a 32-bed clinical cancer research hospital at Oak Ridge.

Program begun to supply all radioisotopes being sold to qualified cancer research workers in the United States without production charges.

Sponsored research, and provided radioisotopes, to determine the efficiency of radiocobalt (cobalt 60) as a substitute for radium in treatment of cancer.

A 16-curie gamma source was first used in the outdoor field at Brookhaven National Laboratory to irradiate plant material.

1950

May

December 11
Facilities to conduct studies on range cattle exposed to fallout in New Mexico in 1945 completed at the University of Tennessee - Atomic Energy Research Laboratory.

With approval of the National Security Resources Board, AEC initiated training courses in radiological monitoring and the detection and treatment of radiation injury to assist in the national civil defense planning program.

The hospital under the Medical Division, Oak Ridge Institute of Nuclear Studies, opened for study of the treatment of malignant diseases with radioactive materials.

AEC established maximum permissible level for chronic exposure to beta, ganma, and $X$-rays as 0.3 roentgen per week to blcod forming organs and established maximum permissible concentrations for 10 radicactive isotopes in drinking water, air and the human body.

1951

12,000 mice exposed to weapons detonations in Pacific Tests, in biological effects tests.

Demonstration at Argonne National Laboratory of effectiveness of spleen shielding in combating the effects of exposure to radiation.

First automatic medical scanning devices designed for outlining the configuration of the thyroid gland at the University of California at Los Angeles. 
J anuary

July 1

November

December

December

1954

March 1

September

July 1
Completion of Aquatic Biology Laboratory, Hanford Works.

Opening of Radiological Laboratory at the University of California Medical Center, San Franctsco - the Comission's third facility devoted to cancer research and which houses a $70 \mathrm{Mev}$ accelerator.

A charge of 20 percent of production cost instituted for radioisotopes used in cancer study, diagnosis and treatment.

Completion of Biology Laboratory, Argonne National Laboratory.

Completion of Biology Laboratory, Brookhaven National Laboratory .

Argonne Cancer Research Hospital completed at a cost of $\$ 4,180,000$-- the largest facility ever designed and built specifically for the purpose of applying atomic energy to the diagnosis, study, and treatment of cancer and closely allied diseases.

Completion of Health Research Laboratory at Los Alamos Scientific Laboratory.

Accidental exposure of Marshallese Is lands and Japanese fishing vesse 1 to fallout. Thirty-one American test per sonnel and 236 Marshallese were exposed to radiation.

First use of 184-inch synchrocyclatron in human patient for irradiation of pituitary gland to retard cancer growth at the University of California, Berkeley.

1955

Development of whole body counter employing multicrystal arrays of solid crystals at Argonne National Laboratory.

Program of supplying radioisotopes without production costs to qualified cancer research workers extended to medical and agricultural users of radioisotopes in the U. S.

1956 
June 29

1958

December 16

1959

March 15

Late Spring
Release of radiation-improved strain of "Sanilac" navy bean in Michigan.

The Commission approved for application to all. Commission operations a series of revised maximum permissible levels of radiation exposures based on recommendations of the NCRP.

Natives of Rongelap Atoll repatriated to their home is land.

Discovery of dose rate effect in production of matations in male mice.

Pirst phase of a long-term ecological survey of Rongelap Atoll undertaken.

Studies at Oak Ridge National Laboratory show that the mutation rate in the female mouse as compared with acute radiation is lower after chronic irradiation.

Dedication of the Brookhaven Medical Research Center.

Release of radiation-improved strain "N. C. 4X" peanut in North Carolina.

Fifty Mev moving beam, linear accelerator for medical use placed in operation at the Argonne Cancer Research Hospital.

Medical Research Reactor, Brookhaven National Laboratory achieved criticality.

Laboratory scale studies at the University of Tennessee Atomic Energy Agricultural Laboratory demonstrated that up to 94 percent of contained strontium can be removed from milk without appreciable alteration of the milk.

Initiation of bioenvironmental studies in Alaska for Project Chariot on a scale never before carried out simultaneously in any area.

Studies at the unshielded Lockheed (Georgia) reactor site demonstrated the hitherto unsuspected sensitivity of pine trees to radiation.

In plant material studies at Brookhaven National Laboratory, it was established that, in general, the larger the volume of the cell nucleus, the smaller the amount of radiation required to inhibit growth of the plants. 
Chemical toxicity studies of nickel at the Jefferson Medical College (Philadelphia), produced lung cancer in experimental animals.

Construction of 1,521-foot tower at Nevada Test Site to support reactor simulator of bomb radiations to obtain dosimetry data for studies of the Japanese survivors of Hiroshima and Nagasaki. Experiment termed Bare Reactor Experiment (Nevada) - BREN.

Publication of revised edition of "The Effects of Nuclear Weapons."

Oak Ridge National Laboratory development of two semiconductor detectors make possible heretofore unattainable accuracy in the energy analysis of beta and gamma radiation.

1963

Initiation of long-range comprehensive fallout studies program at Livermore Laboratory, University of California.

Joint research program established between the AEC and the National Cancer Institute, National Institutes of Health to study the interaction of radiation and chemicals as a possible cause of cancer.

Development of a high-speed zonal ultracentrifuge for large scale isolation and purification of viruses through cooperative efforts by specialists in the biological and physical sciences at Oak Ridge.

Success achieved in attempt to measure the complete spectrum of electrons generated by ionizing radiation in matter using the "keplertron" at Oak Ridge National Laboratory.

Early Initiation of AEC plant sciences research program at Michigan State University. Construction of facilities expected to be completed in 1965.

Construction of laboratory facilities to house Fission Product Inhalation Project to be conducted for the AEC by the Lovelace Foundation for Medical Education and Research (Albuquerque) completed. 